HEROES AND MARTYRS OF QUALITY AND SAFETY

\title{
Ernest Amory Codman MD
}

\section{Neuhauser}

Qual Saf Health Care 2002;11:104-105

E rnest Amory Codman MD (1869-1940) was a Boston surgeon. Like all of us he was human and made mistakes. Unlike others he made a lifelong systematic effort to follow up each of his patients years after treatment and recorded the end results of their care. He recorded diagnostic and treatment errors and linked these errors to outcome in order to make improvements. He was sufficiently disgusted with the lack of such outcomes evaluation of care at the Massachusetts General Hospital where he was on the staff that he resigned to start his own private hospital which he called the "End Result Hospital".

From 1911 to 1916 there were 337 patients discharged from Codman's hospital. He recorded 123 errors and measured the end results for all these patients. He grouped errors by type. There were errors due to lack of knowledge or skill, surgical judgment, lack of care or equipment, and lack of diagnostic skill. In addition to the errors there were four "calamities of surgery or those accidents and complications over which we have no known control. These should be acknowledged to our selves and to the public and study directed to their prevention".

The difference between Codman's hospital and your healthcare organisation is that he admitted his errors in public and in print. They are all described in the annual report of his hospital. Codman paid out of his own pocket to publish this report so that patients could judge for themselves the quality and the outcome of care. He sent copies of his annual reports to major hospitals throughout the country challenging them to do the same. If he were alive and with you today, he would ask in a gentle way why your hospital does not do the same. Your patients want to know.

Here is one of Codman's cases from his End Result Hospital report:

"Case \#90. Jan 27 1913. Stout female - 36. Abdom. pain of 12 hours duration Pre-op diag. subacute appendicitis. Op. (EAC and GWM) - Appendectomy. Appendix showed evidence of a previous attack but no sign of acute inflammation. Comp. none. [Error in diagnosis, Ed]. Result August 1913 well. August 18 1915. Now has symptoms of gallstones. Op. advised, scar solid."

Note that (1) even today this seems a plausible description of misdiagnosed appendicitis, (2) the patient is followed up years after discharge to demonstrate the "end result" of care, and (3) one can link process error to end result. In this case the patient has a new problem of gallstones not related to the diagnostic error.

Then there was patient number 77. Codman ligated the hepatic duct which led to the patient's death: "I had made an error of skill of the most gross character and even (during the operation) failed to recognize that I had made it".

After the description of his last patient Codman says: "Reminder. You may or may not agree with the criticism indicated by the symbols; of course they are open to doubt; but the point is this, at our charitable hospitals there is no one who dares make such criticism at all. It is the duty of no one and it is for the interest of no one-except for the patients and for the community" (page 109).

The annual report of Codman's hospital publicly reported errors at the rate of one error for every three patients. Codman

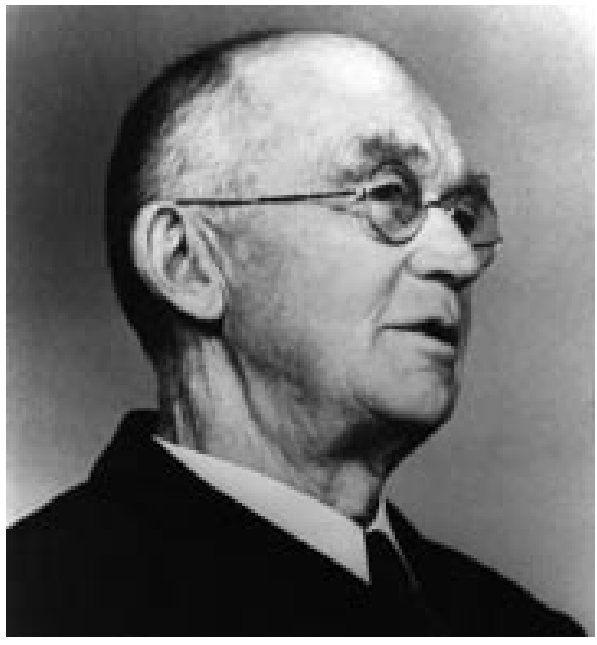

would ask you in public to give the error rate for your hospital. You might reply that your lawyers would not let you say. Codman would reply "humbug". If your patients only knew what the care in your hospital was really like, would they come? Covering up your errors and humbugging the public is how you make money. "I am naturally disgusted with humbug, self-deception, hypocrisy, smugness, cupidity and injustice" (The Shoulder xxxvii). Hiding behind the lawyer's skirts is no answer. Codman has nailed us.

Perhaps Codman's hospital had lots of errors because the surgeons were not very good. Codman was a founder of the American College of Surgeons along with such colleagues as George W Crile (founder of the Cleveland Clinic) and Charles $\mathrm{H}$ Mayo. Mallon in his biography of Codman calls him "one of the most important surgeons of the twentieth century". Also operating at the End Result Hospital was an even more famous surgeon, Codman's medical school classmate Harvey Cushing, generally referred to as the founder of neurosurgery. You can read how Cushing misdiagnosed patient number 86 in the annual report. In short, your hospital would be lucky to have surgeons of this calibre. Yet errors were made by the very best.

Codman's good deeds and high mindedness were punished, of course, thus qualifying him as a "martyr of quality".

In August 1911 Codman resigned his full time position at the Massachusetts General Hospital and opened his hospital in November of that year. His lifetime average income from practice was $\$ 6000$ per year. It rose to $\$ 10000$ by 1914 .

On 6 January 1915 he presented a large cartoon at a meeting of the local Surgical Society which he chaired. It portrays greedy surgeons grasping for gold from wealthy patients (portrayed as an ostrich with its head buried in Boston's prosperous Beacon Hill). Humbugs marched along the border. He was trying to get his "end result" message across and he created an uproar. He was ostracised for this public insult by his colleagues and his income that year plummeted to $\$ 5000$. He 
was ordered to step down as Chair of the Society and for decades after he was an embarrassment to members of the extended Codman family.

Mallon says his reforming efforts "brought him mostly ridicule, poverty and censure". He never stopped in his effort to link care, errors, and end results and to measure, report, and improve. Some day we will catch up with his work.

To learn more about Codman, first read his 1917 End Result Hospital report (Codman EA. A Study in Hospital Efficiency. Reprinted by the Joint Commission on Accreditation of Healthcare Organizations Press, 1 Renaissance Blvd, Oakbrook Terrace, Illinois 60181,1996$)$. The going price for an original copy will be about $\$ 1000$ if you can find one. Codman was a fine writer and his opinions are clear. Paraphrasing his words usually dilutes them.

Next read Codman's autobiography in The Shoulder (privately printed, Boston, 1934 and reprinted since then). Here he reproduces his cartoon and graphs his life on one page including his yearly income. Such public disclosure of personal income is not something a proper Bostonian would do. On this page he lists his publications under the heading "advertisements". Most of these papers appeared in what is today called the New England Journal of Medicine. He said most clinical research told only of very good results and were therefore mere advertisements. Real improvement would be made, he believed, when clinicians wrote about their errors and how to reduce them.

Now you are ready for William Mallon's excellent full length biography Ernest Amory Codman: The End Result of a Life in Medicine (Philadelphia: WB Saunders, 2000). Mallon is an orthopaedic surgeon who does justice to Codman's important surgical contributions.

Also read Michael Millenson's Demanding Medical Excellence (Chicago: University of Chicago Press, 1997). Millenson describes today's transformation of medicine based on evidence and accountability. In chapter 7 he shows how Codman's work was a forerunner in the modern search for medical excellence.

\section{Correspondence to:}

D Neuhauser, Epidemiology and Biostatistics, Medical School, Case Western Reserve University, Cleveland, Ohio 44106-4945, USA; dvn@po.cwru.edu

\section{2nd Asia Pacific Forum on Quality Improvement in Health Care}

Raffles City Convention Centre, Singapore

11-13 September 2002

\section{Call for papers}

We are delighted to announce this forthcoming three day conference in Singapore.

The themes of the Forum are:

- Improving patient safety

- Leadership for improvement

- Measuring quality and benchmarking for change

- Education and training for improvement

- Improving health systems

- Improving the care of patients with chronic disease

- The evidence for quality improvement.

Call for papers deadline Friday 5 April 2002.

Presented to you by the BM Publishing Group (London, UK) and the Institute for Healthcare Improvement (Boston, USA).

For more information email: quality@bma.org.uk or register online at www.quality.bmjpg. com

Tel: +44 (0) 207383 6409; Fax: +44 (0) 2073836869 